\title{
612 気泡周囲の液相流動構造之時物質移動の相互関係
}

Mutual relationship between the liquid flow structure around a bubble and its instantaneous mass transfer ○学 黄 潔（静大工）

Jie HUANG, Faculty of Engineering, Shizuoka University

\section{学 野畑 慶紀（静大院）}

Yoshinori NOBATA, Graduate School of Engineering, Shizuoka University
正 齋藤 隆之（静大グリーン研）

Takayuki SAITO, Research Institute of Green Science and Technology, Shizuoka University

Key Words: Mass transfer, bubble, liquid flow

\section{1. 粕言}

気液二相流は多くの工業装置 (バイオ反応器, 化学反応器, 廃水処理装置）に広く見られる，特に，工業プロセスにおい ては, 気泡流が多用されている、気泡流の場合, 気泡・気泡 間の干渉, 気泡・液相間の干渉が強く，非常に複雑である. まず, 単一気泡と液相間の詳細な干渉メカニズムを理解する ことが不可欠である。

本研究では，水槽の底に設置された注射針から単一 $\mathrm{CO}_{2}$ 気泡(物質移動係数が最大になる球等価直径が $2 \sim 3 \mathrm{~mm}^{(1)}$ の気 泡)を高精度に制御して生成し(2), 高速度カメラ 2 台を用いて 2 方向から高時間・空間分解能でこの運動を撮影した。さら に, 独自の画像処理手法により気泡の 3 次元構造を再現し, 気泡の体積を求めた. $\mathrm{CO}_{2}$ の溶解によって減少した微小体積 を基に, 瞬時物質移動係数を求めた. 加えて, 気泡の上昇運 動と界面運動を精密に捉えて, これらと瞬時物質移動係数と を対比させながら，瞬時の物質移動メカニズムを考察する．

\section{2. 実験装置}

\section{2-1 気泡投影画像撮影}

Fig.1 に気泡投影画像撮影を目的とする実験装置の概略を 示す. 脱気したイオン交換水を矩形水槽(a)に満たした. 水槽 の底に設置された皮下注射針(c)（内径 $0.4 \mathrm{~mm}$ ) と 2 つの圧力 コントローラ, 増幅器, オーディオスピーカから構成された

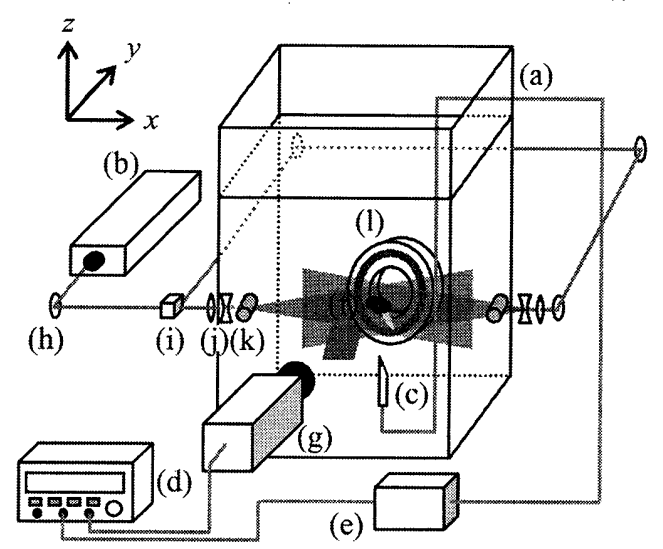

(a) Vessel \& water, (b) Ar ion laser system,

(c) Hypodermic needle, (d) Function generator,

(e) Bubble generator, (f) Bubble,

(g) High-speed camera, (h) Mirror, (i) Half mirror,

(j) Beam expand, (k) Rod lens, (l) LED light

Fig. 1 Experimental setup for bubble projection images. 気泡発生装置(e)を用い, 初期の形状, 輝度, 運動, 姿勢が一 様な気泡を射出した.アルゴンイオンレーザー(b)（INNOVA $70 \mathrm{C}$, 波長: $488 \mathrm{~nm}$ ）をハーフミラー(i)で 2 方向に分光し, ビ ームエキスパンダー $(\mathrm{j})$ によ拡大して, 気泡撮影のバックラ イトとした. また，ファンクションジェネレータ(d)を用い, 気泡射出と 2 台の高速度カメラ $(\mathrm{g})$ (Phantom, 露光時間: $10 \mu \mathrm{s}$, 空間分解能: $6.01 \mu \mathrm{m} / \mathrm{pixel}$, 解像度: $1024 \times 1024$ pixels） の撮影 のタイミングを同期させて，ジグザグ運動平面 ( $x-z$ 面) と その直交平面 $(y-z$ 面）を同時に撮影した. 高速度カメラで 撮影した画像に独自の画像処理を施し, 気泡の長軸・短軸長, 体積ならびに表面積等を算出した.

\section{2-2 物質移動過程可視化}

Fig. 2 にLIF/HPTS 実験の実験装置を示す. 微量の蛍光物 質 HPTS (8-hydroxypyrene-1，3，6-trisulfonic acid，励起波長 $455 \mathrm{~nm}$, 発光強度 $520 \mathrm{~nm}$ ) を水に混入し, アルゴンイオンレ 一ザー(b)によって，これを励起・発光させた. 気泡から $\mathrm{CO}_{2}$ が溶解すると液相の $\mathrm{pH}$ が変化し, HPTS の発光強度が低下 する.すなわち, $\mathrm{CO}_{2}$ の溶解した液相部分が暗くなることに よって, $\mathrm{CO}_{2}$ の物質移動過程を容易に可視化できる. リング 状 LED ライト(波長 $660 \mathrm{~nm})(\mathrm{l})$ をバックライトとして, 気泡の 輪郭を高速度カメラ $(\mathrm{g})$ で明瞭に撮影した。

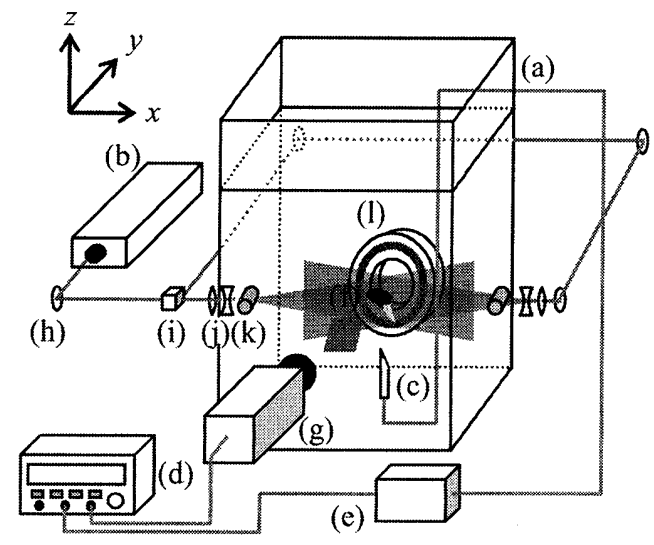

(a) Vessel \& water, (b) Ar ion laser system,

(c) Hypodermic needle, (d) Function generator,

(e) Bubble generator, (f) Bubble,

(g) High-speed camera, (h) Mirror, (i) Half mirror,

(j) Beam expand, (k) Rod lens, (l) LED light

Fig. 2 Experimental setup for the LIF/HPTS method. 


\section{3. 気泡体樌の算出プロセス}

Fig. 3 は, 気泡の正面 $\left(x-z\right.$ 面)における長軸長 $a_{\text {front }}$ と側面 $(y-z$ 面)における長軸長 $a_{\text {side }}$ の比を表わしている. この比がほぼ 1 になっていることから, 気泡の上面 $(x-y$ 面)すなわち, 気泡の 進行方向から見る形状は軸対称な楕円之考えてよい。

高速度カメラで撮られた画像から気泡の正面, 側面, 上面 の投影形状を抽出する. 長軸の傾斜を水平にすると, Fig.4 に示すように，軸対称な棈円であることが分かる． Fig.5 に 示したように, 正面, 側面から得られた気泡の長軸 $L_{x}, L_{y}$ と短軸 $L_{z}$ を辺とする直方体の軸の長さとしてモデル(a)を構 筑した. 次に, 抽出された気泡の正面投影形状(b) と側面投影 形状と直方体モデルの合致した部分(c)を抽出した. 気泡の進 行方向から見る気泡の形状が軸対称な棈円という特徴(d)を 考慮して，3D の気泡形状(e)を構築した。 さらに, 得られた 3D の気泡を非常に薄く分割し, 各スライスの体積を算出し て, 気泡の体積を高精度に求めた。

\section{4. 結果及び考察}

Fig.6 に, 気泡の(a)軌道 $x-z,(\mathrm{~b})$ 速度 $\left(v_{x}{ }^{2}+v_{z}^{2}\right)^{0.5}$, (c) 表面積 $S_{\text {bubble, }}$, (d) 物質移動係数 $k_{L}$, (e) 体積减少率 $d V_{\text {bubble }} / d t$ の結果を 示した. なお, 物質移動倸数 $k_{L}$ は下式により求めた.

$$
N_{a v e}=k_{L}\left(c_{S}-c_{\infty}\right)=-\rho \frac{\Delta V}{S \cdot \Delta t}
$$

ここで， $N_{a v e}$ は平均質量流束， $c_{S}$ 之 $c_{o}$ はそれぞれ界面に おける濃度とバルク濃度である. 気泡体積減少量 $\Delta V$, 気泡 の表面積 $S$, シャッター速度 $\Delta t$ は実験データから得た.

Fig.6(a)に示されているように,気泡が射出されてから, $15 \mathrm{~mm}$ 付近まで直線上昇運動し，その後, ジグザグ運動する.なお, 気泡直後を $(\mathrm{A})$, 第一変更点 $(B)(20 \mathrm{~mm}$ 付近 $)$, 第二変更点 $(\mathrm{C})$ (40mm 付近) とする. Fig.6(b), (c), (d)から, 気泡速度, 表面積ならびに物質移動速度が区間(A)-(B)で増加する。こ の区間における物質移動速度の増加は, 気泡に作用する浮力 による加速と気泡形状の変化（円形から扁平な楕円）による 表面積の増加による. (d) と体積変化率(e)はほぼ同一の変化 を示している. 区間(A)-(B)において, 気泡は加速され, 気 泡上部の液相更新が促進され, 気泡後部（下部）に濃度が輸 送される。気泡は(B)で終端速度（約 $300 \mathrm{~mm} / \mathrm{s}$ )に達し，(C) まで等速に移動する.この間，気泡表面積は減少するが， $k_{L}$ はほぼ一定值を保つ. 気泡周囲の液相運動による輸送が影響 しているためと考えられる. (C)で気泡後部から馬蹄形渦が 放出されており(3)，物質移動が促進されることによっで(4), $k_{L}$ が増加する.

Fig.7 は, HPTS を用いて $\mathrm{CO}_{2}$ の溶解過程を可視化した結果 である. 同図に示すように，(a)は射出した直後の気泡，(b) は第二変向点後の気泡である. (a)では, 気泡直下に暗い領域 (○で示した部分）が存在する.これは気泡下部に蓄積され た $\mathrm{CO}_{2}$ の高濃度域を表わしている. 気泡の上昇運動に伴う気 泡周囲の液相運動により,気泡下部に渦構造が形成され, $\mathrm{CO}_{2}$ の集積領域ができたものと考えられる. (b)では, 気泡のジグ ザグ運動によって, 気泡後流において馬蹄形渦が放出されて いる.この馬蹄形渦により対流拡散がさらに発達し，(a)に示 された $\mathrm{CO}_{2}$ の蓄積領域が消失した. 以上より, 気泡が旋回す る際に放出された馬蹄形渦によって物質移動が促進された と考光られる.

\section{引用文献}

(1) M. Motarjemi et al., Chem. Eng. Sci., 33 (1978) 1415

(2) Saito, T., et al., Chem. Eng. J., 158 (2010), 39

(3) Brucker, C., Phys. Fluids, 11 (1999) 1781

(4) J. Khinast et al, Chem. Eng. Sci., 58 (2003) 3961

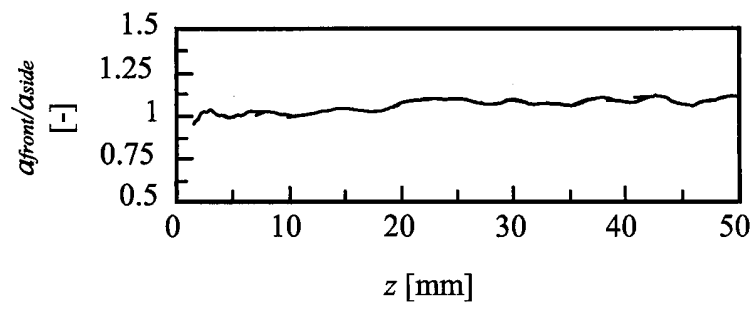

Fig.3 The ratio of bubble's major axis to minor axis.

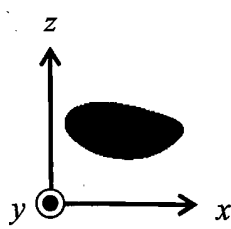

(a) $x-z$

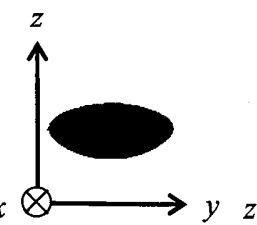

(b) $y-z$

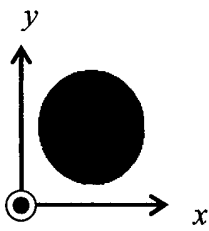

(c) $x-y$
Fig.4 Bubble shape on $x-z, y-z$, and $x-y$ plane.

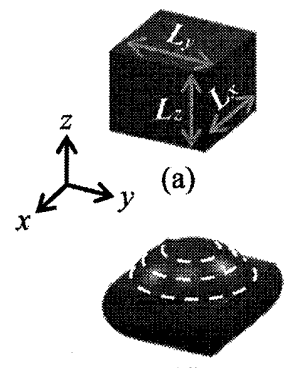

(d)

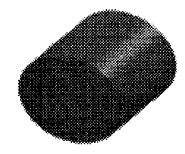

(b)

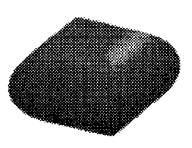

(c)

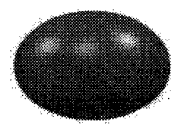

(e)
Fig.5 Algorithm for the calculation of bubble.

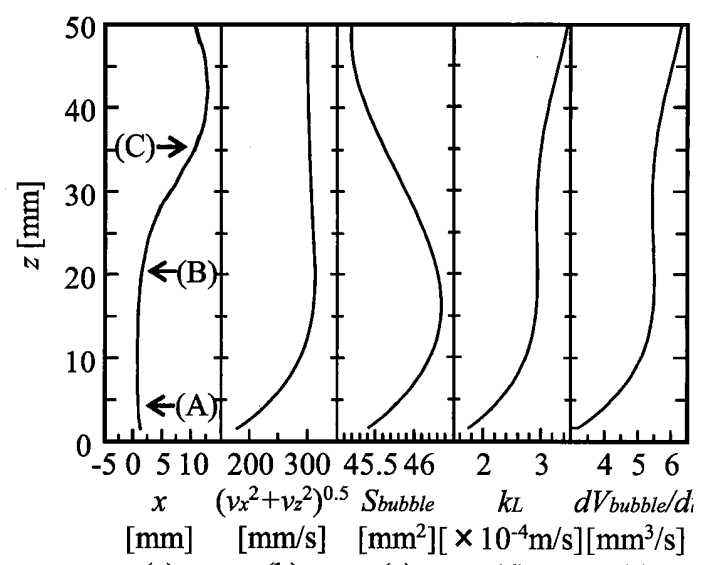
(a)
(b)
(c)
(d)

(e)

Fig.6 Bubble trajectory, bubble volume, surface area, mass transfer coefficient, and velocity.

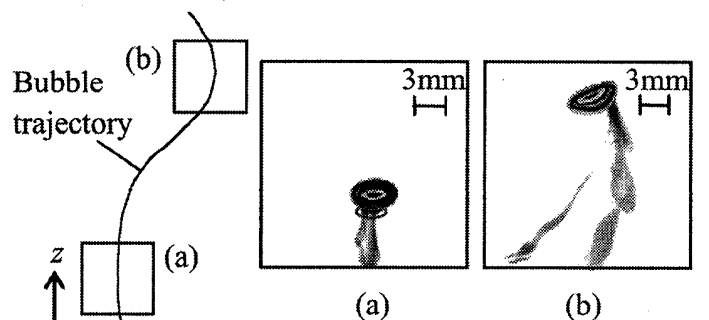

Fig.7 Visualization of the bubble wake. 